Original Research Article

\title{
Effect of promethazine on seizure activity and its interactions with antiepileptic drugs diazepam and phenytoin in Rats
}

\author{
Sandesh Warudkar', Vinod Shinde ${ }^{2 *}$, Archana Borkar ${ }^{3}$
}

${ }^{1}$ Department of Medical

Services, Cadila Healthcare

Limited, Ahmedabad, Gujarat, India

${ }^{2}$ Department of Pharmacology,

Smt. Kashibai Navale Medical

College and General Hospital,

Nahre, Pune, Maharashtra, India

${ }^{3}$ Department of Pharmacology,

NKP Salve Institute of Medical

Sciences and Research Centre,

Nagpur, Maharashtra, India

Received: 08 May 2018

Accepted: 14 May 2018

*Correspondence to:

Dr. Vinod Shinde,

Email: vshinde62@gmail.com

Copyright: (C) the author(s), publisher and licensee Medip Academy. This is an openaccess article distributed under the terms of the Creative Commons Attribution NonCommercial License, which permits unrestricted noncommercial use, distribution, and reproduction in any medium, provided the original work is properly cited.

\begin{abstract}
Background: Current antiepileptic drugs (AEDs) are effective in controlling seizures in about $70 \%$ patients but use is often limited by adverse effects. Promethazine, $\mathrm{H} 1$ receptor antagonist, has a controversial status in patients of epilepsy. Both pro and antiepileptic effect has been documented in various animal studies. Hence, this study was designed to see the effect of promethazine, an H1 antihistaminic drug and its interactions with antiepileptic drugs in rats.

Methods: The effect of promethazine $(10 \mathrm{mg} / \mathrm{kg})$ and its interactions with antiepileptic drugs diazepam and phenytoin was assessed by using maximal electroshock seizures (MES) and chemoshock (PTZ) method.

Results: Promethazine along with diazepam in subtherapeutic doses exerted significant protection against MES induced seizures whereas no such protection was observed with PTZ method rather the seizure threshold was reduced.

Conclusions: Subtherapeutic doses of Promethazine alone and in combination with diazepam showed protection against seizures in MES method. However, proconvulsant effect was seen with PTZ method suggesting histamine plays a protective role in development of seizures. This shows dual behavior of promethazine on MES and PTZ induced seizures.
\end{abstract}

Keywords: Diazepam, MES, Pentylenetetrazol, Phenytoin, Promethazine

\section{INTRODUCTION}

Epilepsy is a chronic neurological disorder that affects people of all ages. Around 39 million people worldwide and 7 million in India have epilepsy. ${ }^{1,2}$ Epilepsy is more common in older people. ${ }^{3,4}$ In the developed world, onset of new cases occurs most frequently in babies and the elderly. ${ }^{5}$ In the developing world, onset is more common in older children and young adults, due to differences in the frequency of the underlying causes. ${ }^{6}$ Current antiepileptic drugs are effective in controlling seizures in about $70 \%$ of patients but their use is often limited by adverse effects. Antiepileptic drugs are among the most common classes of drugs responsible for either isolated cutaneous reactions. "Antiepileptic Hypersensitivity Syndrome" is a severe dose independent, idiosyncratic reactions to aromatic anticonvulsants like phenytoin and carbamazepine that may result in end organ damage. ${ }^{7,8}$

Histamine plays important role in cutanous adverse drug reactions caused due to drug hypersensitivity., ${ }^{9,10}$ Also histamine has stimulatory effects upon neurons. It also has suppressive ones that protect against the susceptibility to 
convulsions, drug sensitization, denervation, supersensitivity, ischaemic lesions and stress. ${ }^{11}$ Antihistaminics may play a crucial role in management of cutaneous ADR caused due to antiepileptic drugs. Promethazine, $\mathrm{H}_{1}$ receptor antagonist is an antiallergic and antiemetic drug having an additional centrally acting anticholinergic property. But, there is controversy regarding use of promethazine as an antihistaminic agent in patients of epilepsy. Both pro and antiepileptic effect of promethazine has been documented in various animal studies. ${ }^{12-17}$ Hence the present study was designed to study the effect of promethazine on seizure activity and its interactions with antiepileptic drugs diazepam and phenytoin in rats using subtherapeutic doses.

\section{METHODS}

The study protocol was approved by Institutional Animal Ethics Committee (IAEC). All the pharmacological experiments were conducted using albino rats $(n=10)$, weighing between 150 and 200g. The animals were maintained under controlled environmental conditions such as temperature $\left(21 \pm 2^{\circ} \mathrm{C}\right)$, relative humidity (30$70 \%$ ), and photoperiod of $12 / 12 \mathrm{~h}$ period. They were provided with standard commercial pelleted diet and Aquaguard drinking water ad libitum. They were acclimatized for at least 7 days before the start of experiments. Convulsive tests were carried out between 12.00-15.00 hrs.

Drugs used were injections of promethazine, diazepam and phenytoin. Solutions of these drugs were prepared freshly in desired strength in water. Drugs were injected intraperitoneally (i.p.). All drugs were given in subtherapeutic doses, which were decided by trial and error method. Experimental design for the study was: ${ }^{18}$

- Group I: Control: 0.1ml/100 gms

- Group II: Promethazine alone

- Group III: Antiepileptic drug alone (Diazepam or Phenytoin)

- Group IV: Promethazine + Antiepileptic drugs (Diazepam or Phenytoin)

Methods of convulsive tests selected:

\section{Supramaximal Electroshock Seizures $(\mathrm{MES})^{19}$}

Rats were tested for tonic hind limb extensor phase (TEP) of electroshock seizure with a convulsiometer using current strength of $150 \mathrm{~mA}$ for 0.2 seconds through the ear electrode. ${ }^{20}$ During screening rats not showing typical extensor phase were discarded. For observing interaction of promethazine with antiepileptic drugs 10 rats were pretreated with subtherapeutic dose of promethazine, 10 rats with diazepam or phenytoin and another 10 rats with combination of promethazine and antiepileptic drugs (diazepam or phenytoin)

\section{Chemically induced seizure $(P T Z)^{21}$}

Pentylenetetrazol (PTZ) was given intraperitoneally (ip.) in a dose of about $70 \mathrm{mg} / \mathrm{kg}$ producing seizures in $100 \%$ rats without any mortality. Observations were made for 30 minutes for convulsions to occur after injection of PTZ. Rats were divided in group of $10 .^{22}$ Potentiation of PTZ convulsions by promethazine was elucidated further by taking subtherapeutic dose of PTZ with subtherapeutic dose of promethazine. The effect of promethazine in combination with antiepileptic drugs diazepam and phenytoin was also compared using PTZ method.

\section{Statistical analysis}

All values are expressed as percentage of animals showing protective effect. Comparison of percentage protection in promethazine, diazepam, phenytoin, and promethazine + diazepam or phenytoin with control was done by proportion test. ${ }^{18}$ Data was analyzed on STATA statistical software. $\mathrm{P}$ values $<0.05$ was considered as statistically significant and $\mathrm{p}<0.01$ as highly significant.

\section{RESULTS}

Effect of promethazine, and antiepileptic drugs diazepam and phenytoin alone and in combination against MES are shown in Table 1 and 2. It shows that there was 20\%, 30\% and $20 \%$ protection with promethazine, diazepam and phenytoin alone. While promethazine in combination with diazepam and phenytoin showed $80 \%$ and $20 \%$ protection of which initial was highly significant $(\mathrm{p}<0.01)$.

Table 1: Effect of promethazine and diazepam alone and in combination using electroshock (MES) method in rats.

\begin{tabular}{|c|c|c|c|c|}
\hline Drugs & Dose (mg/kg) & $\begin{array}{l}\text { Number of } \\
\text { animals }\end{array}$ & $\begin{array}{l}\text { Percentage of animals protected } \\
\text { showing abolition of extensor phase }\end{array}$ & p-value \\
\hline Control & & 10 & 00 & -0.1360 \\
\hline Promethazine & 10 & 10 & 20 & -0.0603 \\
\hline Diazepam & 2 & 10 & 30 & \\
\hline Promethazine+diazepam & $10+2$ & 10 & 80 & $\begin{array}{l}\mathbf{\square} 0.008^{* *} \\
\square 0.0136\end{array}$ \\
\hline
\end{tabular}

- $\mathrm{p}$ value of Promethazine, Diazepam and Prometazine + Diazepam is compared with Control

$\square$ p value of Promethazine + Diazepam is compared with addition of Promethazine and Diazepam

* p value $<0.05$ is significant

** $\mathrm{p}$ value $<0.01$ is highly significant 
Table 2: Effect of promethazine and phenytoin alone and in combination using electroshock (MES) method in rats.

\begin{tabular}{|c|c|c|c|c|}
\hline Drugs & Dose (mg/kg) & $\begin{array}{l}\text { Number of } \\
\text { animals }\end{array}$ & $\begin{array}{l}\text { Percentage of animals protected } \\
\text { showing abolition of extensor phase }\end{array}$ & p-value \\
\hline Control & & 10 & 00 & \\
\hline Promethazine & 10 & 10 & 20 & $=0.1360$ \\
\hline Phenytoin & 5 & 10 & 20 & 口0.1360 \\
\hline Promethazine+Phenytoin & $10+5$ & 10 & 20 & $\begin{array}{l}\square 0.1360 \\
\square 0.2733\end{array}$ \\
\hline
\end{tabular}

- $\mathrm{p}$ value of Promethazine, Phenytoin and Prometazine + Phenytoin is compared with Control; $\square \mathrm{p}$ value of Promethazine + Phenytoin is compared with addition of Promethazine and Phenytoin; * $\mathrm{p}$ value $<0.05$ is significant; ** $\mathrm{p}$ value $<0.01$ is highly significant

Table 3 shows seizure producing effect of combination of promethazine (fixed dose) with pentylenetetrazol (PTZ). It shows that graded doses of PTZ alone at a dose of 30, 40 and $50 \mathrm{mg} / \mathrm{kg}$ do not produced convulsions in rats. Convulsions were observed in $40 \%$ of animals at a dose of $60 \mathrm{mg} / \mathrm{kg}$ and in $100 \%$ of animals at a dose of $70 \mathrm{mg} / \mathrm{kg}$ of PTZ without any mortality. Promethazine in a fixed subtherapeutic dose of $10 \mathrm{mg} / \mathrm{kg}$ in combination with graded dose of PTZ showed $70 \%$ convulsions at $30 \mathrm{mg} / \mathrm{kg}$ and $100 \%$ convulsions at a dose of $40,50,60,70 \mathrm{mg} / \mathrm{kg}$ dose of PTZ with decreasing order of average time of onset of convulsion and increase in mortality. Table 4 and 5 shows effect of promethazine, diazepam and phenytoin alone and in combination by using Chemoshock seizure induced by pentylenetetrazol. Results shows that there was $00 \%, 30 \%$ and $20 \%$ of animals were protected with promethazine, diazepam and phenytoin respectively. With combination of promethazine this protection was $30 \%$ and $00 \%$ in diazepam and phenyoin group resp. which was not significant $(\mathrm{p}>0.05)$.
Table 3: Seizure producing effect of combination of promethazine (fixed dose) with pentylenetetrazol (PTZ).

\begin{tabular}{|lllll|}
\hline $\begin{array}{l}\text { Promethazine } \\
(\mathrm{mg} / \mathrm{kg})\end{array}$ & $\begin{array}{l}\mathrm{PTZ} \\
(\mathrm{mg} / \mathrm{kg})\end{array}$ & $\begin{array}{l}\text { Animals } \\
\text { convulsing } \\
(\%)\end{array}$ & $\begin{array}{l}\text { Average } \\
\text { time of } \\
\text { onset of } \\
\text { convulsion } \\
(\mathrm{min})\end{array}$ & Mortality \\
\hline-- & 30 & 00 & & 00 \\
\hline-- & 40 & 00 & & 00 \\
\hline-- & 50 & 00 & & 00 \\
\hline-- & 60 & 40 & 14 & 00 \\
\hline 10 & 70 & 100 & 11 & 00 \\
\hline 10 & 30 & 70 & 13.5 & 00 \\
\hline 10 & 40 & 100 & 08 & 00 \\
\hline 10 & 50 & 100 & 8.5 & 02 \\
\hline 10 & 60 & 100 & 5 & 02 \\
\hline 10 & 70 & 100 & 3.1 & 03 \\
\hline
\end{tabular}

Table 4: Effect of promethazine and diazepam alone and in combination using chemoshock (PTZ) method in rats.

\begin{tabular}{|c|c|c|c|c|}
\hline Drugs & Dose (mg/kg) & $\begin{array}{l}\text { Number of } \\
\text { animals }\end{array}$ & $\begin{array}{l}\text { Percentage of animals protected } \\
\text { showing abolition of tonic clonic phase }\end{array}$ & p-value \\
\hline Control & & 10 & 00 & \\
\hline Promethazine & 10 & 10 & 00 & - \\
\hline Diazepam & 0.5 & 10 & 30 & $\mathbf{n} 0.0603$ \\
\hline Promethazine + diazepam & $10+0.5$ & 10 & 30 & $\begin{array}{l}=0.0603 \\
\square 1.00\end{array}$ \\
\hline
\end{tabular}

- $\mathrm{p}$ value of Promethazine, Diazepam and Prometazine + Diazepam is compared with Control; $\square \mathrm{p}$ value of Promethazine + Diazepam is compared with addition of Promethazine and Diazepam; * $\mathrm{p}$ value $<0.05$ is significant; $* *$ p value $<0.01$ is highly significant

Table 5: Effect of promethazine and phenytoin alone and in combination using chemoshock (PTZ) method in rats.

\begin{tabular}{|lllll|}
\hline Drugs & Dose $(\mathrm{mg} / \mathrm{kg})$ & $\begin{array}{l}\text { Number of } \\
\text { animals }\end{array}$ & $\begin{array}{l}\text { Percentage of animals protected } \\
\text { showing abolition of tonic clonic phase }\end{array}$ & p-value \\
\hline Control & & 10 & 00 & - \\
\hline Promethazine & 10 & 10 & 00 & $\mathbf{0}$ \\
\hline Phenytoin & 5 & 10 & 20 & 0.1360 \\
\hline Promethazine+phenytoin & $10+5$ & 10 & 00 & $\square 0.1287$ \\
\hline
\end{tabular}

- $\mathrm{p}$ value of Promethazine, Phenytoin and Prometazine + Phenytoin is compared with Control; $\square \mathrm{p}$ value of Promethazine + Phenytoin is compared with addition of Promethazine and Phenytoin; * $\mathrm{p}$ value $<0.05$ is significant; $* * \mathrm{p}$ value $<0.01$ is highly significant 


\section{DISCUSSION}

The present work investigated the effect of Promethazine, a $\mathrm{H} 1$ receptor antagonist, on seizure activity and its interactions with antiepileptic drugs diazepam and phenytoin in rats. The results of the present work provided evidence that subtherapeutic doses of promethazine alone and in combination with diazepam showed significant protection against tonic hind limb extensor phase (TEP) of electroshock seizures and this combination may have beneficial results in grandmal seizures.

In contrast to electroshock method when promethazine $(10 \mathrm{mg} / \mathrm{kg})$ was tested alone and in combination with antiepileptic drugs in chemoshock method, it did not show any protection rather a proconvulsant action was seen, suggesting histamine plays a protective role in the development of convulsions. Hence its use in petitmal or absence seizures cannot be recommended.

The exact underlying mechanisms of such dual behavior of promethazine on MES and PTZ induced seizures are unclear. The reason may be the essential difference between the mechanism of tonic extension and that of clonus. When promethazine was tested by PTZ induced seizures for experimental activity, it significantly reduced threshold for seizures. The possible explainations for proconvulsant activity of promethazine could be:

- Blockade of histamine induced opening of homomultimeric $\mathrm{GABA}_{\mathrm{A}}$ recepors. ${ }^{23}$

- Blockade of $\mathrm{H}_{1}$ receptor mediated reduction of a background $\mathrm{K}^{+}$current in cenral neuron. ${ }^{24}$

- Selective inhibition of brain NaK-ATPase. ${ }^{25}$

Promethazine also has centrally acting antcholinergic properties. It is postulated that acetylcholine plays a role in proconvulsant action of the muscarinic agonist pilocarpine used in experimental models of human epilepsy. It is observed that stimulation of brain muscarinic receptors cause persistent tonic clonic convulsions suggesting enhancement of muscarinic neurotransmission as a mechanism of induction of seizure activity by agents that inhibit neural acetylcholinesterase (e.g. organophosphate inhibitors). ${ }^{26}$

It is well known that GABAergic and glutaminergic mechanisms are directly associated with the seizure activity. ${ }^{27}$ When histamine diffuses away from its synapse to a glutamate synapse containing NMDA receptors, it can act at an allosteric modulatory site called the polyamine site, to alter the actions of glutamate at NMDA receptors. The role of histamine and function of this action are not well clarified. ${ }^{28}$

Further, $\mathrm{H}_{1}$ receptor activation causes excitation in most brain regions (brainstem, thalamus, hypothalamus, cortex, amygdala, striatum) through Gq11 protein and a direct block of a leak potassium conductance or phospholipase inositol triphosphate (IP3) and diacylglycerol (DAG) mediation. IP3 releases calcium ions from internal stores and activates a number of calcium dependent processes, including opening of a cation channel (TRPC) or the stimulation of $\mathrm{Na}^{+}-\mathrm{Ca}^{++}$exchanger $(\mathrm{NCX}){ }^{29}$ Centrally acting anticholinergics like promethazine by blocking $\mathrm{H} 1$ receptors can interfere with functions in these important brain regions.

The results of present study are in consistent with the previous study conducted by Tanaka et al who reported anticonvulsant activity of some local anaesthetics, some antihistaminics, spasmolytics, analgesics and some other miscellaneous drugs. ${ }^{17}$ Majority of these drugs caused excitation and convulsions in toxic doses. The toxic convulsion was always type of clonic seizure and tonic extension never occurred. Hence, they coined a new term 'antiextensors' in order to avoid contradictory explanation such as "anticonvulsant property" of convulsant drugs.

In the present study it was found that promethazine was capable of preventing tonic extension in MES seizures but when promethazine was tested by PTZ induced seizures for its experimental activity, it significantly reduced threshold for seizures. In combination with antiepileptic drugs, the anticonvulsant activity of promethazine is limited to electroshock seizure and no protection was afforded by these compounds against PTZ convulsions. Rather, it tends to facilitate the clonic seizures of PTZ.

\section{Limitations}

- Results of animal study cannot be fully extrapolated to human epilepsy and seizures. It has to be concluded by a clinical study.

- $\quad$ Promethazine has a strong sedative action and hence concurrent use with benzodiazepines is again a limiting factor for clinical use of promethazine in the management of epilepsy.

- $\quad$ Problem of convulsive phenomena creates a degree of background concern about its use.

- More needs to be known about the difference in the mechanism of action of promethazine on MES and PTZ induced seizures which will help to decide the safety of use of promethazine in grandmal and petitmal epilepsy.

\section{CONCLUSION}

Authors can extrapolate finding of present study that promethazine reduces seizure threshold in PTZ induced seizures to conclude that the use of promethazine in combination with antiepileptic drugs in petitmal seizures cannot be recommended.

Combination of promethazine with diazepam showed highly significant protection against MES induced seizures. Promethazine in combination with phenytoin did not show any protection against MES induced seizures. So, this combination is not likely to have any clinical significance. 


\section{ACKNOWLEDGEMENTS}

The help rendered by Mr. Khapre, Laboratory assistant, NKPSIMS and RC-Nagpur, is duly acknowledged.

Funding: No funding sources

Conflict of interest: None declared

Ethical approval: The study was approved by the Institutional Ethics Committee

\section{REFERENCES}

1. Disease GBD, Injury I, Prevalence C. Global, regional, and national incidence, prevalence, and years lived with disability for 310 diseases and injuries, 1990-2015: a systematic analysis for the global burden of disease study 2015. Lancet. 2016;388(10053):1545-602.

2. World Health Organization. Epilepsy. Fact sheet No. 999. January 2009. Available at: http://www.who.int/mediacentre/

factsheets/fs999/en/print.html. Accessed 7/23/2013

3. Brodie MJ, Elder AT, Kwan P. Epilepsy in later life. The Lancet Neurology. 2009;8(11):1019-30.

4. Holmes, Thomas R. Browne, Gregory L. Handbook of epilepsy ( ${ }^{\text {th }}$ Ed.). Philadelphia: Lippincott Williams and Wilkins; 2008:7. ISBN 978-0-7817-7397-3. Archived from the original on 29 May 2016.

5. Wyllie's treatment of epilepsy: principles and practice $\left(5^{\text {th }}\right.$ Ed.). Philadelphia: Wolters Kluwer/Lippincott Williams and Wilkins; 2010. ISBN 978-1-58255-9377. Archived from the original on 24 June 2016.

6. Newton CR. Epilepsy in poor regions of the world. The Lancet. 2012;380(9848):1193-201.

7. Rang HP, Dale MM. Antiepileptic drugs, In: Pharmacology $5^{\text {th }}$ Edition; Churchil Livingstone, Elsevier sciences Limited, Edinburgh; 2003:550.

8. Schlienger RG, Shear HN. Antiepileptic drug hypersensitivity syndrome. Epilepsia. 1998;39(7):S37.

9. Hennino A, Berard F, Guillot I, Saad N, Rozières A, Nicolas JF. Pathophysiology of urticaria. Clin Rev Allergy Immunol. 2006;30:3-11.

10. Drain KL, Volcheck GW. Preventing and managing drug induced anaphylaxis. Drug Saf. 2001;24:843-53.

11. Tedeschi DH, Benigni JP, Elder CJ. Effects of various phenothiazines on minimal electroshock seizure threshold and spontaneous motor activity of mice. The J of Phar and Exp Therapeu (JPET). 1958;123:35-8.

12. Kamel C, Ohuch M, Sugimoto Y, Okuma C. Mechanism responsible for epileptogenic activity by first generation $\mathrm{H} 1$ antagonists in rats. Brain Res. 2000;887(1):183-6.

13. Scherki R, Hashem A, Frey H. Histamine in brain, its role in regulation of seizure susceptibility. Epilepsy Research. 1991;10:111-18.

14. Saper CB, Chou TC, Scammell TE. The sleep switch: Hypothalamic control of sleep and wakefulness. Trends Neurosci. 2001;24:726-31.
15. Sen P, Khanna N, Ray A. Histaminergic mechanisms in experimental convulsions. Indian J Exp Biol. 1991 Apr;29(4):375-8.

16. Saxena VC, Bapat SK, Dhawan BN. An experimental evaluation of the anticonvulsant activity of some antihistaminic drugs. Jap J Pharmacol. 1969;19:47784.

17. Tanaka K, Kawasaki Y. A group of compounds possessing anticonvulsant activity in the maximal electroshock seizure in rats. Jap $\mathbf{J}$ Pharmacol 1957;6:115-21.

18. Dashputra AV, Borkar AS, Hemnani TJ, Badwaik RT. Effect of ketamine on seizure activity and its interactions with antiepileptic drugs in rats. IJMPS. 2012;03(02):01-8.

19. Huwiler A. Electroshock in mice. In: Vogel HG, editor. Drug Discovery and Evaluation: Pharmacological Assays. $3^{\text {rd }}$ Ed, Vol. 1. SpringerVerlag: Berlin, New York; 2008:692-693.

20. Swinyard EA, Brown WC, Goodman. Comparitive assay of antiepileptic drugs in mice and rats. J pharmacol express Ther. 1952;106:319.

21. Huwiler A. Pentylenetetrazole (Metrazol) induced convulsions. In: Vogel HG, editor. Drug Discovery and Evaluation: Pharmacological Assays. $3^{\text {rd }}$ Ed, Vol. 1. Springer-Verlag: Berlin, New York; 2008:613-614.

22. Richard RK, Everett GM. Analgesics and anticonvulsant properties of 3,5,5 trimethylloxazolidine, 2-4 dione (Tridione). Fed Proc. 1944:39-44.

23. Saras A, Glosslmann G, Vogt- Elsele AK, Erlkamp KS. Histamine action on vertebrate GABAA receptors. Direct channel gating and potentiation of GABA responses., The $\mathrm{J}$ of Bio Chemis. 2008;283(16):10410-475.

24. Sangalli BC. Role of histaminergic neuronal system in the CNS toxicity of the first generation $\mathrm{H} 1$ antagonists. Progress in Neurobiology. 1997;52(2):145-57.

25. Hovart A, Momic T, Bunjac A, Petrovic S. Selective Inhibition of brain Na,K- ATPase by drugs. Physiol. 2006;55:325-38.

26. Kai MS, Hirvonen MR. Second messengers in cholinergic induced convulsions and neuronal injury. Toxicology Letters. 1992;437-45.

27. Belousov AB, O'hara BF, Denisova JV. Acetylcholine becomes the major excitatory neurotransmitter in the hypothalamus in vitro in the absence of glutamate excitation, The J of Neurosc. 2001;21(6):2015-17.

28. Stahl SM. Stahl's Essentials Psychopharmacology, $3^{\text {rd }}$ Edition, NewYork, NY Cambridge Univerity Press; 2008:1027-1034.

29. Hass H, Paulima P. Histaminergic system in brain, Nat Rev Neurosci. 2003;121-30.

Cite this article as: Warudkar S, Shinde V, Borkar A. Effect of promethazine on seizure activity and its interactions with antiepileptic drugs diazepam and phenytoin in Rats. Int J Basic Clin Pharmacol 2018;7:1100-4. 